The Geoffrey Hartman Reader 



\section{The Geoffrey Hartman Reader}

Edited by

GEOFFREY HARTMAN AND DANIEL T. O'HARA

Edinburgh University Press 
(C) Geoffrey Hartman (extracts/readings), 2004

(C) Geoffrey Hartman and Daniel T. O'Hara (editorial selection and arrangement), 2004

(C) Daniel T. O’Hara (Introduction), 2004

\section{Edinburgh University Press Ltd}

22 George Square, Edinburgh

\section{Typeset in Bembo}

by Hewer Text Ltd, Edinburgh, and

printed and bound in Great Britain by

The Cromwell Press, Trowbridge, Wilts

A CIP record for this book is available from the British Library

ISBN 0748620168 (hardback)

ISBN 0748620176 (paperback)

The right of Geoffrey Hartman

to be identified as author of this work

has been asserted in accordance with

the Copyright, Designs and Patents Act 1988. 